\title{
Time, costs and farmers' perceptions: The case of livestock service delivery in tamilnadu
}

\author{
G kathiravan*, M. Thirunavukkarasu ${ }^{1}$ and S. Selvam ${ }^{1}$ \\ Veterinary College and Research Institute, namakkal, Tamilnadu, India. \\ 1. Madras Veterinary college, Chennai, India. \\ * corresponding author email: drkathir@tanuvas.org.in \\ Published online at www.veterinaryworld.org on 25-03-2011
}

\begin{abstract}
A study was undertaken in southern peninsular State of India, the Tamil Nadu State, (i) to ascertain the time costs of animal health care and bovine breeding services, and (ii) to comprehend the perceptions of farmers on the livestock services rendered by different service providers. The districts of the state were categorized as 'Livestock Developed' (LD) and 'Livestock Under Developed' (LUD) based on initial base line developed. Travel, waiting and service time were among the primary non-price factors that affected service quality. Average travel time was highest for visiting the public veterinary centre in both LUD (23.05 min.) and LD (21.32 min.) districts. Waiting time with regard to veterinarians providing home services in LUD districts was highest (23.01 $\mathrm{min}$.), followed by public veterinary centre services at LUD districts (22.35 min.), home services by para-veterinarians (22.01 min.) and public veterinary centre services at LD districts (20.10 min.). Both travel and waiting time were much higher in case of breeding services compared to curative services, which could be due to the fact that the farmers preferred Artificial Insemination (AI) over its close substitute, the natural service. However, the service time was relatively less in case of insemination services vis-à-vis curative services both in LUD and LD districts. The quality perceptions of farmers on livestock services revealed that the home services rendered by veterinarians as the best one $(0.83)$, followed by private veterinary clinics $(0.75)$, home services by para-veterinarians $(0.74)$, public veterinary centres $(0.64)$ and co-operative veterinary centres $(0.48)$.
\end{abstract}

Key words: Livestock services; Travel time; Waiting time; Service time; Service quality; India

\section{I ntroduction}

Livestock sector plays a significant role in the Indian economy, particularly for the welfare of rural population of India. Of the total households in the rural area, about 73 per cent own some form of livestock. There is also an inverse relationship between land and livestock holdings, excluding landless category (Ravishankar and Birthal, 1999), indicating better equity of farmers with respect to livestock holding. More importantly, small and marginal farmers account for three quarters of these households. The economic liberalization has widened the market opportunities for the livestock sector. There are expectations of faster growth in demand for livestock products due to expected increase in income combined with the highincome elasticity of demand for livestock products. However, the sector's ability to capitalize on new market opportunity is constrained by the availability and quality of support services.

Effective and efficient delivery of animal health and production services is considered as vital for gainful livestock development and hence, efficient delivery of livestock services has become a subject of rising concern to many national and international organisations including FAO (Kleeman, 1999).

Livestock services are critical for enhancing productivity and competitiveness. In India, the Government maintains a large public infrastructure on livestock services, but there are questions about the service utility and reach to the livestock producers (Planning Commission, 2007).

Although co-operative and private operators are in the field, the extent of their share in the sector is very meagre. The present structure of livestock services delivery in India is based on fixed model of a Veterinary Hospital/Dispensary/Sub-centre being the key nodal structure at the ground level from where services and goods are currently distributed.

The extent to which growth in livestock production can be accelerated would depend on how technology, institutions and policies address constraints facing the livestock sector. In the past, growth in livestock production was largely numberdriven, while the future would be from improvements in productivity. This will require overcoming feed and 
Time, costs and Farmers' perceptions: The case of Livestock service delivery in Tamilnadu

Table-1. Average time costs associated with animal health care services

\begin{tabular}{|c|c|c|c|c|c|c|}
\hline Service provider type & District type & Travel time & Waiting time & Service time & Total time & "t" Value (minutes) \\
\hline Public veterinary centre & $\begin{array}{l}\text { LUD } \\
\text { LD }\end{array}$ & $\begin{array}{l}23.05(5.00-60.00) \\
21.32(5.00-35.00)\end{array}$ & $\begin{array}{l}22.35(15.00-45.00) \\
20.10(15.00-30.00)\end{array}$ & $\begin{array}{l}12.11(5.00-20.00) \\
14.50(5.00-30.00)\end{array}$ & $\begin{array}{l}57.51(30.00-75.00) \\
56.32(25.00-60.00)\end{array}$ & $0.129^{N}$ \\
\hline Home service by veterinarian & $\begin{array}{l}\text { LUD } \\
\text { LD }\end{array}$ & $\begin{array}{l}0.00 \\
0.00\end{array}$ & $\begin{array}{l}23.01(15.00-60.00) \\
15.38(10.00-25.00)\end{array}$ & $\begin{array}{l}23.59(15.00-35.00) \\
25.18(10.00-45.00)\end{array}$ & $\begin{array}{l}47.00(35.00-70.00) \\
40.56(25.00-70.00)\end{array}$ & $0.189^{\mathrm{NS}}$ \\
\hline Ethnic/ traditional healer & $\begin{array}{l}\text { LUD } \\
\text { LD }\end{array}$ & $\begin{array}{l}9.07(5.00-15.00) \\
10.29(8.00-30.00)\end{array}$ & $\begin{array}{l}12.00(5.00-20.00) \\
12.35(5.00-25.00)\end{array}$ & $\begin{array}{l}11.00(10.00-30.00) \\
10.59(5.00-40.00)\end{array}$ & $\begin{array}{l}32.07(25.00-40.00) \\
33.23(20.00-45.00)\end{array}$ & $0.360^{\mathrm{NS}}$ \\
\hline Private veterinary clinic & $\begin{array}{l}\text { LUD } \\
\text { LD }\end{array}$ & $\begin{array}{l}14.00(5.00-20.00) \\
20.05(10.00-25.00)\end{array}$ & $\begin{array}{l}15.00(10.00-25.00) \\
15.00(10.00-25.00)\end{array}$ & $\begin{array}{l}5.00(3.00-10.00) \\
5.00(3.00-10.00)\end{array}$ & $\begin{array}{l}34.00(20.00-45.00) \\
40.05(20.00-50.00)\end{array}$ & $0.380^{\mathrm{NS}}$ \\
\hline
\end{tabular}

Figures in parentheses indicate range of time; ${ }^{\text {Ns }}$ Not-significant (P 0.05).

fodder scarcity and improvements in delivery of animal health and breeding services. The quality service means ensuring timely availability with adequate infrastructure and medicaments.

In the light of above context, this study was undertaken in Tamil Nadu, (i) to ascertain the time costs of animal health care and bovine breeding services, and (ii) to comprehend the perceptions of farmers on the livestock services rendered by different service providers. The study will provide an insight into the existing quality of livestock services and ultimately aiding in any plan for quality improvement.

\section{Material and Methods}

Following Selvakumar et al. (2002), the districts of Tamil Nadu State were categorized as 'Livestock Developed' (LD) and 'Livestock Under Developed' (LUD) based on initial base line data gathered using the value of livestock output, rural human population and common property resources available for livestock farming. Four districts, two each from livestock 'Developed' (Coimbatore and Villupuram districts) and 'Under Developed' (Thanjavur and Sivagangai districts) areas were selected randomly. From the districts so selected, a total number of 320 farmers ( 80 from each district) were chosen by adopting multistage random sampling technique. Information on the accessibility of veterinary services, transport time, waiting and service time involved to get their animals treated or bred; the farmers' observation on the quality parameters of the services, etc., were collected by personal interview through the structured and pilot-tested interview schedule. The data collected were subjected to descriptive and Student's t statistical analyses.

\section{Results and Discussion}

Average time costs of animal health care services: Travel, waiting and service time are among the primary non-price factors that affect service quality (Ahuja et al., 2000). Table 1 displays the average time costs associated with animal health care services in the study area. Although average travel time was highest for visiting the public veterinary centre in both LUD (23.05 min.) and LD (21.32 min.) districts, the magnitude was much higher in LUD districts. This could be explained by the fact that the LD districts had a dense network of veterinary institutions over LUD districts. Travel time for visiting private veterinary clinics in LUD districts was 14.00 minutes, while the same was 20.05 minutes in case of LD districts, which could be due to the fact that the number of cases attended to at private veterinary clinics in LUD districts was more than that of LD districts. Besides, the private clinics in LD districts were located in the townships alone, concentrating mainly on pet animals.

The waiting time in Table 1 refers to the time lag between the first contact with the service provider and the receipt of service. Waiting time with regard to veterinarians providing home services in LUD districts was highest (23.01 min.), followed by public veterinary centre services at LUD districts (22.35 min.), home services by para-veterinarians (22.01 min.) and public veterinary centre services at LD districts (20.10 $\mathrm{min}$.). The least waiting time was for pharmacy dispensed medication in both categories of districts. Longer waiting time in case of home services could be attributed to the travel time needed for the service providers to reach the farmers' home, after the call.

Interpretation of service time is relatively more difficult since it depends on a number of factors such as complexity of disease, ability of service provider to diagnose and provide treatment quickly, attention paid by service provider, including the time taken to explain the level of sickness to the farmers, provide advice on after care, etc., (Ahuja et al., 2000). Thus, while high service time could be due to the complexity of the case, with the service provider paying a great deal of attention in treating the animal, it could also be a reflection of the ability of service provider to provide quick diagnosis and treatment. Notably, the average 
Time, costs and Farmers' perceptions: The case of Livestock service delivery in Tamilnadu

Table-2. Average time costs associated with bovine breeding services

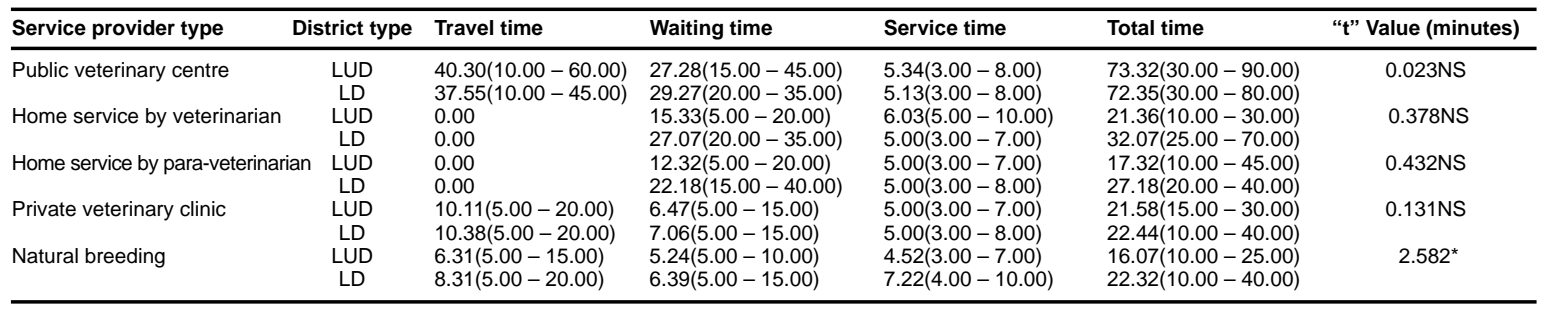

Figures in parentheses indicate range of time; ${ }^{\text {Ns }}$ Not-significant ( $P$ 0.05).

service time was highest for both home services by veterinarians and para-veterinarians in both LUD and LD districts. Further, there was an appreciable time difference between the public veterinary centre services and private home visits in both LUD and LD districts. The average service time for public veterinary centre service was 12.11 minutes in LUD districts and 14.50 minutes in LD districts.

\section{Average time costs of bovine breeding services:} Average travel, waiting and service time for bovine breeding services are presented in Table 2 . Once again, the travel time was highest for availing services from public veterinary centres in LUD districts (40.30 min.), followed by LD districts (37.53 min.). The travel time to reach private veterinary clinics in LD districts was 10.38 minutes, while the same in LUD districts was 10.11 minutes. In contrary to Ahuja et al. (2000)'s view, an important point to be noted here is that both travel and waiting time were much higher in case of breeding services compared to curative services, which could be due to the fact that the farmers preferred artificial insemination over its close substitute, the natural service. However, the service time was relatively less in case of insemination services visà-vis curative services both in LUD and LD districts.

General perceptions of sample farmers on the livestock services: General perceptions of the sample farmers on the quality of livestock services they received from different types of service providers are presented in Table 3 . The picture reveals that the farmers had troubles in availing services from pharmacy shop, private veterinary clinics, and home services by the veterinarians and even by paraveterinarians in the study area. The farmers informed that they had waited for a long time to receive the services both from public veterinary centres $(0.93)$ and private veterinary clinics $(0.83)$, while it was not so in case of ethnic/traditional healers and pharmacy shop. Further, the farmers were able to receive services during emergency from veterinarians extending home services (0.98), from ethnic/traditional healers (1.00) and from para-veterinarians (1.00), while it was difficult to get the service from co-operative and public veterinary centres. The farmers considered the service providers of public veterinary centres, private veterinary clinics, co-operative veterinary centres and veterinarians extending home services were adequately trained and they treated the farmers kindly, taking adequate care of livestock which was not so in case of traditional practitioners. The infrastructural facilities available with public veterinary centres, private veterinary clinics and co-operative veterinary centres were considered to be moderate. The farmers expressed that working hours at public veterinary centres and cooperative veterinary centres were inconvenient with their score being only 0.30 and 0.25 , respectively.

However, working hours of private veterinary clinics, and veterinarians and para-veterinarians serving at door step were considered to be convenient. Inconvenience in the working hours of public veterinary centres could be probably not due to official hours stipulated, but due to low promptness of service provider there. The farmers considered services of pharmacy shop and home services by veterinarian and para-veterinarian as expensive, while the services of public veterinary centres and co-operative veterinary centres were affordable. The overall satisfaction level with the service provider was highest for home services by veterinarian, followed by public veterinary centres and was lowest for pharmacy dispensed 'over the counter' medication. The average perception for the quality of livestock service revealed that the farmers considered the home services rendered by veterinarians as the best one $(0.83)$ followed by private veterinary clinic $(0.75)$, home services by paraveterinarian (0.74), public veterinary centre $(0.64)$ and co-operative veterinary centre $(0.48)$. The overall picture revealed that the quality of livestock services offered by ethnic practitioners was not effective.

\section{Acknowledgement}

The authors are thankful to the authorities of Tamil Nadu Veterinary and Animal Sciences University, Chennai, India for permitting them to carry 
Time, costs and Farmers' perceptions: The case of Livestock service delivery in Tamilnadu

Table-3.General perceptions of farmers on quality of livestock services (scores)

\begin{tabular}{|c|c|c|c|c|c|c|c|}
\hline Quality attribute & $\begin{array}{l}\text { Ethnic/ } \\
\text { Traditional }\end{array}$ & Pharmacy shop & $\begin{array}{l}\text { Public veterinary } \\
\text { Centre }\end{array}$ & $\begin{array}{c}\text { Private veterinary } \\
\text { clinic }\end{array}$ & $\begin{array}{l}\text { Co-op. Veterinary } \\
\text { centre }\end{array}$ & $\begin{array}{c}\text { Home services by } \\
\text { veterinarian }\end{array}$ & $\begin{array}{l}\text { Home services by } \\
\text { para-veterinarian }\end{array}$ \\
\hline $\begin{array}{l}\text { If you need vet. } \\
\text { aid you can access } \\
\text { service provider } \\
\text { without any trouble }\end{array}$ & 0.80 & 1.00 & 0.93 & 1.00 & 0.71 & 1.00 & 1.00 \\
\hline $\begin{array}{l}\text { You wait for long time } \\
\text { before you see the } \\
\text { service provider }\end{array}$ & 0 & 0 & 0.93 & 0.83 & 0.14 & 0.69 & 0.18 \\
\hline $\begin{array}{l}\text { It is easy for you to } \\
\text { receive veterinary aid } \\
\text { during emergency }\end{array}$ & 1.00 & 0.71 & 0.13 & 0.06 & 0 & 0.98 & 1.00 \\
\hline $\begin{array}{l}\text { If you have a question, } \\
\text { you can reach service } \\
\text { provider for help without } \\
\text { any problem }\end{array}$ & 0.14 & 0 & 0.99 & 1.00 & 1.00 & 1.00 & 0.83 \\
\hline $\begin{array}{l}\text { Do you think the staff } \\
\text { members are adequately } \\
\text { trained? }\end{array}$ & 0 & NA & 1.00 & 1.00 & 1.00 & 0.98 & 0.64 \\
\hline $\begin{array}{l}\text { The provider treats } \\
\text { you kindly and takes } \\
\text { adequate care on your } \\
\text { livestock }\end{array}$ & 0.75 & 1.00 & 0.93 & 1.00 & 1.00 & 1.00 & 1.00 \\
\hline $\begin{array}{l}\text { diagnosis and treatment? } \\
\text { Is the examination } \\
\text { and treatment space } \\
\text { sufficient? }\end{array}$ & 0 & NA & 0.86 & 0.67 & 0.40 & NA & NA \\
\hline $\begin{array}{l}\text { Is the waiting area } \\
\text { clean and sufficient? }\end{array}$ & NA & NA & 0.56 & 0.82 & 0.36 & NA & NA \\
\hline $\begin{array}{l}\text { Are the equipment } \\
\text { adequate? }\end{array}$ & NA & NA & 0.76 & 0.34 & 0.18 & NA & NA \\
\hline $\begin{array}{l}\text { Are the working } \\
\text { hours convenient } \\
\text { for you? }\end{array}$ & NA & NA & 0.30 & 1.00 & 0.25 & 0.93 & 0.88 \\
\hline $\begin{array}{l}\text { Is the location of } \\
\text { provider convenient } \\
\text { to you? }\end{array}$ & 1.00 & 0.80 & 0.30 & 1.00 & 0.50 & NA & NA \\
\hline $\begin{array}{l}\text { Sometimes you go } \\
\text { without livestock } \\
\text { services you needed, } \\
\text { because it is too } \\
\text { expensive }\end{array}$ & 0 & 0.71 & 0.01 & 0.44 & 0 & 0.55 & 0.59 \\
\hline Average score & 0.44 & 0.53 & 0.64 & 0.75 & 0.48 & 0.83 & 0.74 \\
\hline
\end{tabular}

NA - Not applicable for the specific service provider

out this piece of work. Also they thank Prof. Dr.Vinod Ahuja, Indian Institute of Management, Ahmadabad for providing valuable inputs.

\section{References}

1. Ahuja, V., et.al. (2000). Agricultural services and the poor: Case of livestock health and breeding services in India,IM, Ahmedabad; The World Bank, Washington, DC and Swiss Agency for Development and Cooperation, Bern. pp. 1-148.

2. Kleeman, G., (1999). Responses of the livestock services delivery and its management to the Asian economic crisis. Proceedings of the workshop on the implications of the Asian economic crisis for the livestock industry held in
Bangkok on 6-9 July 1999, Organised by FAO, UN.

3. Planning Commission, GOI (2007). Report of the working group on Animal Husbandry and Dairying - 11th five year plan (2007-12). New Delhi. pp.232.

4. Ravishankar, A. and S.P. Birthal, (1999).The livestock sector in India: A country report with special emphasis on trade with southeast Asian economies. Proceedings of the workshop on the implications of the Asian economic crisis for the livestock industry held in Bangkok on 6-9 July 99. pp. 213-232.

5. Selvakumar, K.N., N. Meganathan, M. Prabu and V. Palanichamy, (2002). Assessment of research priorities for livestock sector in Tamil Nadu. Report submitted to National Centre for Agricultural Economics and Policy Research, New Delhi. pp.1-38. 